\title{
The Effectiveness of Guided Inquiry Learning Model with Edmodo Assisted to Facilitate Critical Thinking Skills
}

\author{
${ }^{1 *}$ Andri Estining Sejati, ${ }^{2}$ Syarifuddin, ${ }^{3}$ Nasruddin, ${ }^{4}$ Nisa Miftachurohmah, ${ }^{5}$ La Ode \\ Nursalam, ${ }^{6}$ Eko Hariyanto \\ ${ }^{1}$ Geography Education Study Program, FKIP, USN Kolaka, Street Pemuda Nu. 339, Kolaka, \\ Indonesia 93517 \\ ${ }^{2}$ Department of Physics Education, FKIP, UHO, Street HEA Mokodompit Anduonohu, \\ Kendari, Indonesia \\ ${ }^{3}$ Mathematics Education Study Program, FKIP, USN Kolaka, Street Pemuda Nu. 339, \\ Kolaka, Indonesia 93517 \\ ${ }^{4}$ Computer Science Study Program, FTI, USN Kolaka, Street Pemuda Nu. 339, Kolaka, \\ Indonesia 93517 \\ ${ }^{5}$ Department Geography Edication, FKIP, UHO, Street HEA Mokodompit Anduonohu, \\ Kendari, Indonesia 93517 \\ ${ }^{6}$ Agrobusiness Department, UT Kendari, Anduonohu, Kendari, Indonesia \\ *Corresponding Author e-mail: andriest@usn.ac.id
}

Received: July 2021; Revised: September 2021; Published: December 2021

\begin{abstract}
This research aims to develop a learning device based on a guided inquiry model with Edmodo on the subject of earth structure and disasters which is appropriate to practice critical thinking skills of junior high school students. The research subjects were learning devices and class IX students of SMP Negeri 17 Kendari. This research is a development research using the Dick and Carey model. Testing the results of the development of the device in classroom learning using a one group pretest-posttest design. The data analysis technique used quantitative descriptive and qualitative descriptive. The findings from the results of this research are: The validity of learning tools is in good category, the implementation of lesson plans is in good category; the most dominant student activity during learning is making observations; student response to guided inquiry learning model with Edmodo is considered good; completeness of students' concept understanding learning outcomes, the average pretest was 16.47 and posttest was 87.06. While the students' critical thinking skills learning outcomes, the average pretest was 20.53 and posttest was 85.67 . The obstacle encountered during learning is the time required to carry out learning activities beyond the specified time. Based on the discussion of the results and findings, it is concluded that the guided inquiry model learning with Edmodo tool that has been developed on the earth structure and disaster material is appropriate to be used to train the critical thinking skills of junior high school students.
\end{abstract}

Keywords: edmodo, critical thinking skills, guided inquiry model, learning tools

How to Cite: Sejati, A., Syarifuddin, S., Nasruddin, N., Miftachurohmah, N., Nursalam, L., \& Hariyanto, E. (2021). The Effectiveness of Guided Inquiry Learning Model with Edmodo Assisted to Facilitate Critical Thinking Skills. Prisma Sains : Jurnal Pengkajian Ilmu dan Pembelajaran Matematika dan IPA IKIP Mataram, 9(2), 204-219. doi:https://doi.org/10.33394/j-ps.v9i2.4260

https://doi.org/10.33394/j-ps.v9i2.4260

Copyright@ 2021, Sejati et al This is an open-access article under the CC-BY License.

\section{INTRODUCTION}

Government Regulation No. 19 of 2005 concerning National Education Standards article 6 paragraph (1) states that the curriculum for general, vocational, and special education types at the primary and secondary education levels consists of: (a) groups of 
religious subjects and noble character, (b) ) civics and personality group, (c) science and technology, (d) aesthetics, (e) physical, sport and health. The coverage for the science and technology subject group at SMP/MTs/SMPDLB is intended to acquire basic science and technology competencies and cultivate critical, creative and independent scientific thinking skills (Yustika et al., 2017), where the evaluation system is also based on 3 main aspects, namely attitudes, knowledge, and skills properly formulated in K-13. The 2013 curriculum assesses three domains, namely knowledge, attitudes, and skills (Sukariasih, Sahara, et al., 2019).

National Education Regulation Number 23 of 2006 concerning Graduate Competency Standards states that the Science and Technology subject group aims to develop students' logic, thinking and analytical skills. In junior high school education units, this goal can be achieved through content and/or activities in language, mathematics, natural science, social science, skills/vocational, and/or information and communication technology, as well as relevant local content.

Natural Science subjects emphasize inquiry activities: students as learning subjects interact with objects or objects in nature. Students carry out scientific processes, such as observing, describing, classifying, measuring, conducting experiments, analyzing data, and making conclusions. The teacher's role in science learning is as a guide of inquiry (the leader of inquiry). The teacher has the role of facilitating, motivating, directing, and guiding students in inquiry activities. The role of students in science learning is as the inquirer (Nasruddin et al., 2020).

This is in accordance with the objectives of science subjects in the KTSP, namely so that students have the following abilities. First, increasing belief in the greatness of God Almighty based on the existence, beauty and orderliness of His natural creation. Second, develop an understanding of various natural phenomena, science concepts and principles that are useful and can be applied in everyday life. Third, develop curiosity, positive attitude, and awareness of the interplay between science, environment, technology, and society. Fourth, make scientific discoveries to cultivate the ability to think, behave and act scientifically and communicate. Fifth, increase awareness to participate in maintaining, safeguarding, and conserving the environment and natural resources. Sixth, increasing awareness to appreciate nature and all its regularities as one of God's creations. Seventh, increasing science knowledge, concepts, and skills as a basis for continuing education to the next level (Emda, 2017; Ningrum et al., 2015; Sembiring \& Zagoto, 2017).

One of the most important points in science learning is conducting scientific inquiry to foster critical, creative and independent thinking skills (Yustika et al., 2017). According to (Hunaidah et al., 2019) in learning science, students can improve their ability to respond to various problems that have an impact on the material being studied. Therefore, the right model to achieve this goal is to use an inquiry model that can train students to think scientifically critically, creatively and independently in achieving mastery of concepts. According to (Sukariasih, Saputra, et al., 2019) guided inquiry has an impact on students becoming more active and they are able to find their own knowledge. This is related to the concept of knowledge and procedural which is easy to understand if students get their own knowledge through experimentation. Inquiry-based learning is one of the learning models developed to teach students how to think or use their mental processes (Saputra et al., 2021).

Critical thinking is reasonable and reflective thinking that focuses on deciding what to believe or do (Ennis, 1996). By thinking critically, students understand problems better and can find the best answers to the problems they face. The critical thinking process is also a systematic mental activity obtained from someone who is tolerant and open-minded to strengthen his understanding (Saputra \& ; Sukariasih, 2019). Critical thinking can be achieved more easily if a person has the disposition and abilities that can be considered as traits and characteristics of critical thinkers. According to (Hidayati, 2015) said that critical thinking means: aiming to achieve a critical assessment of what we will receive or what we 
will do with logical reasons, using assessment standards as a result of critical thinking in making decisions, implementing various strategies structured and provide reasons for determining and applying these standards, seeking and collecting reliable information to be used as evidence that can support an assessment (Hassoubah, 2004).

The results of the "Third in International Math and Science" survey in 2007 and 2011, conducted by the Global Institute, showed that more than $95 \%$ of Indonesian students were only able to reach the intermediate level, while nearly $40 \%$ of Taiwanese students were able to reach a high level. and advanced (advanced). The results of further analysis for the TIMSS study showed that the questions used to measure students' abilities were divided into four categories, namely: (1) low, measuring abilities to the level of knowing, (2) intermediate, measuring abilities to the level of applying, (3) high, measuring the ability to reasoning level, (4) advance, measuring the ability to reasoning with incomplete information (Kemdikbud 2014). Benjamin S. Bloom, et al (1956) categorizes the cognitive domain into six levels from the simplest to the most complex, namely: knowledge (knowledge, C1), comprehension (understanding, C2), application (application, C3), analysis (analysis, C2), C4), synthesis (synthesis, C5), and evaluation (evaluation, C6). Knowledge (C1), comprehension (C2), application (C3) are categorized as basic-level thinking skills, while analysis (C4), synthesis (C5), and evaluation (C6) are categorized as higher-order thinking skills (Djidu \& Jailani, 2016, 2017; J. Jailani et al., 2018; Miller et al., 2009).

Other data is disclosed by the Program for International Student Assessment (PISA), with the results of its 2009 study placing Indonesia in a ranking below the top 10; from 65 PISA participating countries. Almost all Indonesian students only master lessons up to level three, while many students from other countries can master lessons up to level four, five and six (Kemdikbud, 2014). The results of the two surveys refer to a conclusion that: critical thinking skills of Indonesian students are still low.

The results of the initial observations show that the implementation of learning still emphasizes understanding concepts, has not shown a planned effort to empower students' critical thinking skills, and the student's activeness in learning is still low and the completeness of learning outcomes is still low. Learning activities are generally characterized by the following stages: (1) Initial activities: the teacher opens the lesson, motivates by asking questions; (2) Core Activities: the teacher explains the subject matter, conducts questions and answers, discussions or demonstrations, and concludes; (3) Closing Activity: the teacher writes the conclusion on the blackboard. The lack of students' roles in learning, and the low critical thinking skills of students, can be caused by the strategies applied by teachers in learning that have not been oriented to empowering higher order thinking. According to (Adriani et al., 2019; Balram, 2017; Hunaidah et al., 2019; Wityafrianti, 2013; Yana et al., 2019) conventional learning is one-way, using makeshift tools, passive students, low learning outcomes, and not hone higher order thinking skills

This condition is no longer relevant to the orientation of the current student competency measurement who no longer uses the National Examination (Retnawati et al., 2019) as in previous years. Measurement of student competence focuses on mastering competencies related to literacy and thinking skills (Jailani Jailani et al., 2020; Kurniawan \& Djidu, 2021) which is measured through the Minimum Competency Assessment (AKM) and focus on character strengthening (Djidu \& Retnawati, 2018) which measured through a character survey.

Based on the identification of the problems described above, it is necessary to design learning efforts that require student involvement to be active in the learning process and train students to develop critical thinking and reasoning skills to find concepts independently. With the use of appropriate learning techniques and methods, it is possible for students to be more active in learning because they are more in line with the student's learning style, so it is hoped that learning will run more effectively and efficiently. 
One of the learning models used to train critical thinking skills is inquiry. According to The Standards, inquiry is a variety of activities that involve observing, asking questions, referring to books and other sources to obtain what is already known, planning an investigation, reviewing what is known from simple experimental evidence, using tools and equipment. to collect, analyze, and interpret data, propose answers, explanations and estimates, and communicate results. Inquiry requires identification of the assumptions used, the use of logical and critical thinking and consideration of the explanation of a matter. (National Research Council, 2011). This was also stated by Nasruddin (2020); Jahring (2020) through a guided discovery approach provides the achievement and improvement of students' mathematical reasoning abilities.

Staver and Bay (1987) in Vajoczki, et al (2011) distinguish three types of inquiry according to their objectives, namely: structured inquiry, guided inquiry and open inquiry. According to Piaget (in Slavin, 1997), junior high school students are in the early stages of formal operations, so that children can use their concrete operations to form more complex operations and need to be guided by others. In addition, the provision of minimal or no guidance during instruction is usually less effective than the presence of sufficient guidance, there is also the possibility of negative results, for example, students gain misunderstanding or incomplete knowledge (Nurul H. et al., 2017). Therefore, student activities in learning will be maximized if delivered in an appropriate learning model such as a guided inquiry model. In line with that, Nasruddin (2017) said that the learning model is one of the main factors in the success of learning.

Guided inquiry is a type of inquiry learning model in which the teacher guides students to conduct initial questioning activities and leads to a discussion or an experimental activity. According to (Nasruddin et al., 2020) the teacher's task in guided inquiry is to provide an active learning environment where students can explore and construct their knowledge through interactions with their peers and with their teachers. To conduct learning with guided inquiry, students need to have concrete experience on how to determine problem formulations, hypotheses, variables, collect data and analyze data.

Critical thinking skills are very important to be developed in learning. Research on critical thinking skills has been carried out by Rahmawati (2012), who examines critical thinking skills with guided discovery learning. The results of this study indicate that the use of learning tools through the guided discovery learning method can train critical thinking skills of YDWP Lab Junior High School students. Unesa Surabaya. Suparmi (2013), based on the results of the study, it was concluded that inquiry-oriented biology learning tools implemented in TPS type cooperative learning can improve critical thinking skills and collaboration skills of high school students. Likewise, the results of Fuad's research (2013), which shows that inquiry-based animation learning that has been developed is feasible to use to train students' critical thinking skills. In this study, inquiry-based learning is used as the basis for developing learning tools that aim to improve students' critical thinking skills. Edmodo media is also integrated in the inquiry learning tool developed in this study.

Edmodo is a popular asynchronous online platform used in blended learning. Edmodo has advantages in presenting material, giving assignments, and giving student exams. Edmodo is also efficient in data usage such as using Facebook or WhatsApp social media. According to (Basori, 2013; Gay \& Sofyan, 2017) Edmodo is an asynchronous platform that can present various materials in an interesting way. According to (Halil, 2020) Edmodo makes it easy to upload materials and assign tasks automatically and save on data packages.

One of the concepts in science subjects for class IX according to KTSP is the structure of the earth and disasters. Researchers chose the material of the structure of the earth and disasters, because it is one of the materials related to everyday life. This means that knowledge related to the structure of the earth and disasters needs to be mastered and understood by students through investigation activities. 
To prepare the guided inquiry learning model with Edmodo, teachers need a learning device that is oriented to the learning model. Nur (2011) explains that science learning tools are one of the supporting factors that determine the success of the teaching and learning process, but the availability of these learning tools is felt to be very lacking.

Based on the background of the problem, the researcher is interested in conducting research with the title: "Development of guided inquiry model science learning tools with Edmodo to practice critical thinking skills of junior high school students". The subject chosen is class IX material on earth structure and disasters.

\section{METHOD}

This type of research is developmental research because it develops learning tools based on inquiry to train junior high school students' critical thinking skills. The tools developed are Learning Implementation Plans (RPP), Student Textbooks (BAS), Student Activity Sheets (LKS), and Assessment Sheets (LP).

This research was carried out in 2 (two) stages, namely the first stage is the development stage of learning tools, adapting from the development stage of teaching materials (HL et al., 2020) at the development stage, the develop phase producing teaching materials, after the teaching materials are complete, validation is needed . Validation is required for the feasibility of the development draft with the development standard. The validation carried out involving two validators on the concept understanding test instrument gave the result that the overall concept understanding test developed by the researcher had good validity. Then proceed with a limited trial or trial I, and the second stage is the implementation stage of learning tools.

The concept understanding test instrument was developed in the form of multiple choice questions and essays. The instrument was developed based on the previously formulated indicators/learning objectives. There are 20 multiple choice questions and 7 essay questions which were developed by referring to the original Bloom's taxonomy.

The learning device development model used in this study is the Dick and Carey (2009) model. The trial design used in both the I and II trials was the One Group Pretest-Posttest Design. The test was conducted on 50 students. The research design applied to a group, without a comparison group (control) with the following notation:

\section{$\mathrm{O}_{1} \times \mathrm{O}_{2}$}

Information :

$\mathrm{O}_{1}=$ Pre-test or pre-test to determine students' prior knowledge on conceptual understanding and critical thinking skills before the learning process takes place or before being given treatment.

$\mathrm{X}=$ The treatment given, namely the application of learning tools using a guided inquiry approach.

$\mathrm{O}_{2}=$ Final test or post test to determine understanding of concepts and critical thinking skills after being given guided inquiry learning.

The data analysis technique used in this research was quantitative and qualitative. Qualitative analysis by grouping qualitative data information in the form of responses and suggestions for improvement. Qualitative analysis with three main components, namely data reduction, data presentation, drawing conclusions and verification. Quantitative analysis to process data review expert and student validators. Data in the form of input, feedback, criticism, and suggestions for improvement. The results of the analysis are then used to revise the product developed. The data is then taken by comparing the number of scores obtained with the total number of ideal scores. 


\section{RESULTS AND DISCUSSION}

This section discusses the provision of heat or heat energy given to coconut oil (Organic PCM). Where the process of giving this heat is given at AC voltage but the voltage that enters the heater is set in such a way that the voltage that enters the device is 28.16 Volts. While the current flowing in the heater is about 0.177 Ampere

The learning tools developed refer to the Learning Unit Level Curriculum (KTSP), which includes lesson plans, student textbooks, worksheets and assessment sheets. All the tools in this study have been designed so that they follow the flow of guided inquiry learning with Edmodo.

\section{Learning Device validation result}

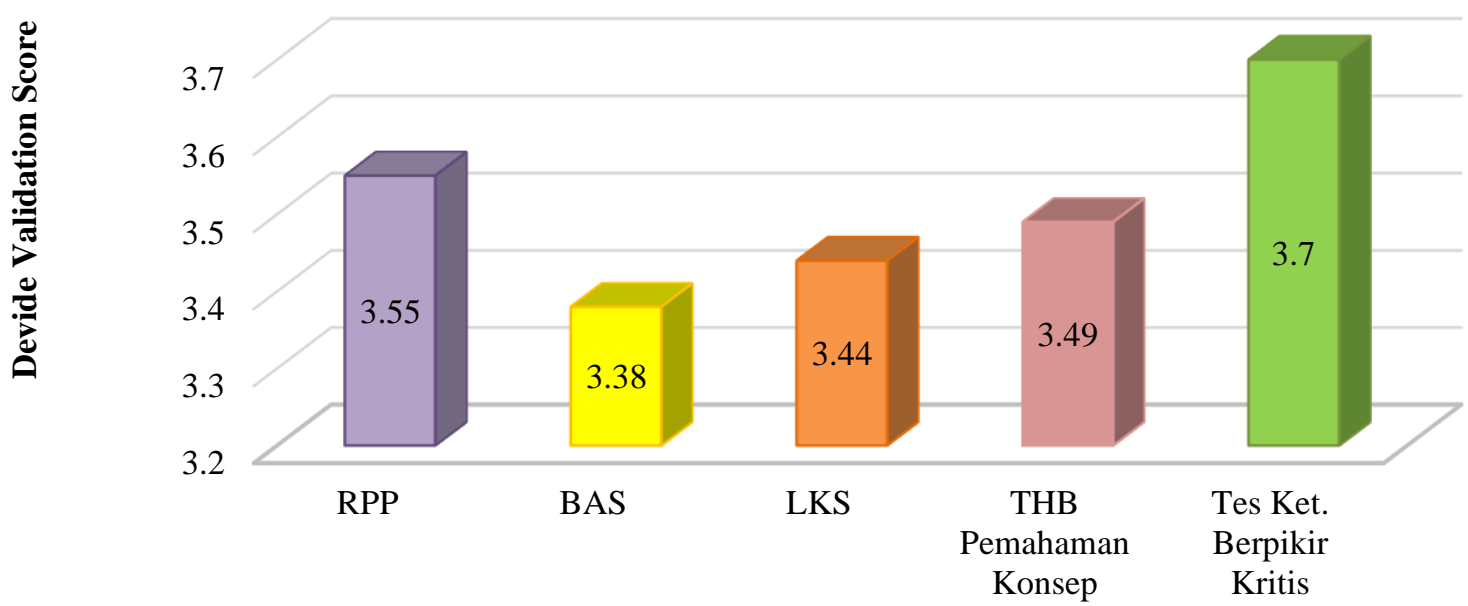

Figure 1. Learning Device Validation Result

The assessment given by the validator on the learning tools that have been developed is good, meaning that all the learning tools developed are feasible and can be used with a few revisions. Based on the results of the validator's assessment, the Learning Plan (RPP) developed is very suitable to be used as a teacher's guide in managing learning on the subject of earth structure and disasters. The achievement of this quality is due to the development of this device has gone through several stages, namely student analysis, learning analysis, and review from supervisors. The good quality of the RPP assessment is also because the preparation of this RPP is guided by Government Regulation number 19 of 2005 concerning BSNP in article 20 which states that the RPP at least contains learning objectives, teaching materials, teaching methods, learning resources and assessment of learning outcomes. In addition, in the context of inquiry learning with Edmodo, researchers adapted from the phases of guided inquiry learning activities according to Meador (2010), Staver and bay (Vajoczki, 2011), and Pavelich and Abraham (1979) into core activities in lesson plans, which includes: (1) goal setting phase, (2) problem formulation phase, (3) hypothesis formulating phase, (4) experiment design phase, (5) data collection phase, (6) data analysis phase, and (7) formulating phase. conclusion. Phase blending with Edmodo makes learning more fun.

The phases of guided inquiry learning activities with Edmodo into this lesson plan are carried out by researchers aiming to open a wider space for active student involvement in inquiry activities, so that students can find their own knowledge through student interaction in learning, both interaction with teachers, interactions with fellow students, interactions with learning media in this case using the Edmodo platform, as well as interactions with various learning resources, especially those that have been uploaded to Edmodo. In this context, 
Dewey (in Arends, 2007) states that teachers need to create a learning environment characterized by democratic procedures and scientific processes where the main responsibility of the teacher is to involve students in inquiry. In addition, the adaptation of guided inquiry learning syntax with Edmodo into lesson plans simultaneously is also intended to train junior high school students' critical thinking skills, namely reasonable reflective thinking based on reasoning to determine what will be done and believed (Ennis, 1985).

The Assessment Sheet is used to measure the achievement of basic competencies that are determined based on the completeness indicators, amounting to $69 \%$. Students are said to have mastered the Basic Competence (KD) if all the indicators on the $\mathrm{KD}$ are complete (Wasis and Irianto, 2008). The basic competencies of the pressure material are broken down into 27 learning objectives for understanding concepts and 10 learning objectives for critical thinking. Based on the learning objectives, an assessment sheet is prepared consisting of: 1) an assessment sheet for understanding concepts, and 2) an assessment sheet for critical thinking skills.

The assessment sheet has been validated. This shows that the assessment sheet is appropriate to be used as a measuring tool for the achievement of KD. The critical thinking test instrument is in the form of description questions based on indicators or learning outcomes that have been formulated previously. The validation carried out by two validators on the critical thinking skills test instrument showed that overall the items were categorized as very good. This shows that the critical thinking skill assessment sheet developed by the researcher is feasible to be used as a critical thinking skill measurement tool. The scoring sheet is then implemented on the Efdmodo platform. According to (Halil, 2020) assessing that Edmodo provides convenience for educators.

The results of the Device Trial related to the implementation of the Learning Implementation Plan are shown in the following figure.

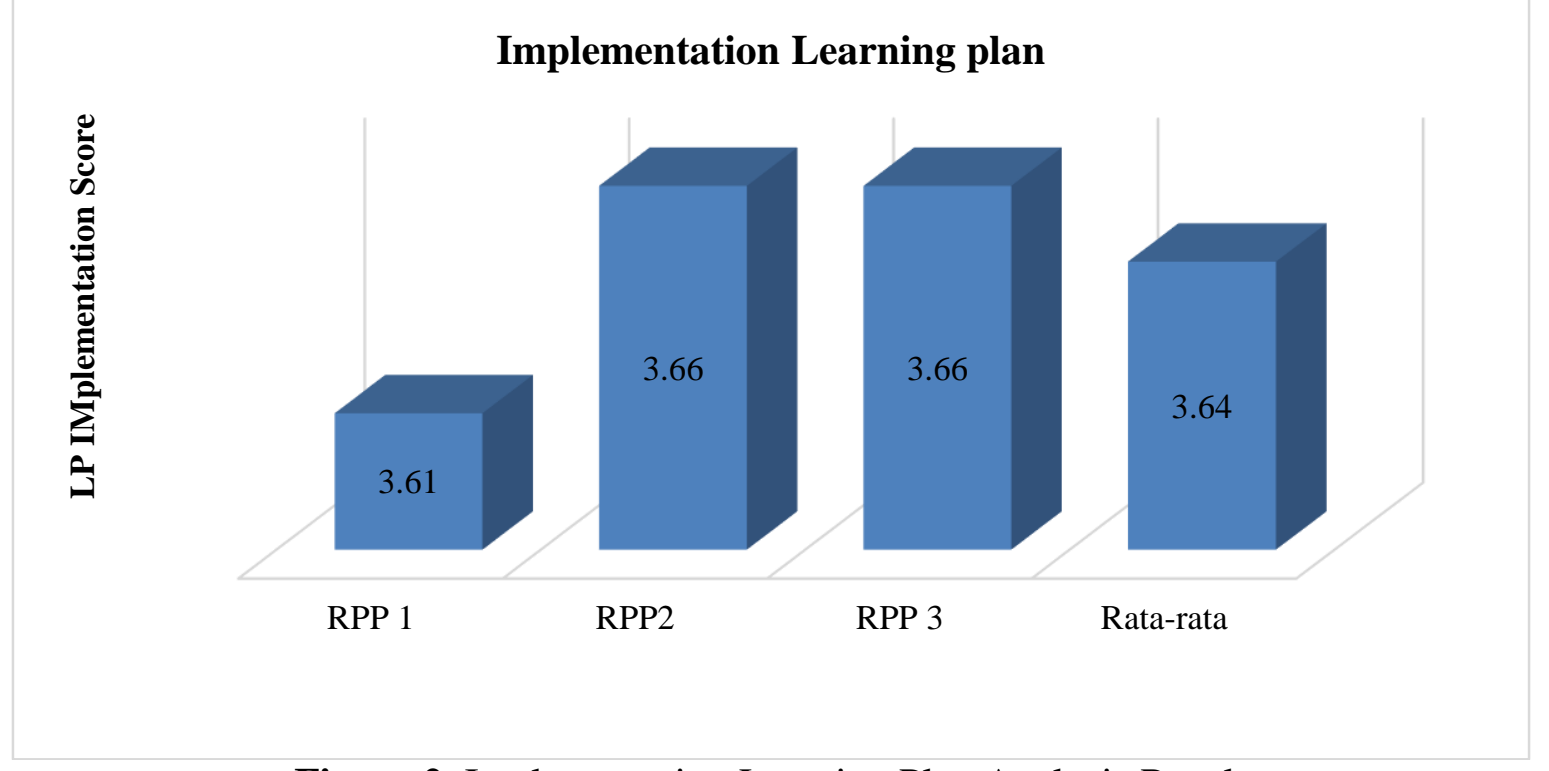

Figure 2. Implementation Learning Plan Analysis Result

Based on Figure 2, it can be seen that the average score of 3.64 indicates that the lesson plan has a very good category (can be seen in Figure 2). The reliability of the instrument for observing the implementation of the RPP is an average of $97 \%$. The percentage of RPP implementation in the second trial was $100 \%$. These results indicate that the implementation of learning has been carried out in accordance with the RPP which has been assessed as good by the validator.

Student activities observed during learning were paying attention to the teacher's explanation, reading or looking for information on teaching materials according to the content, conducting experiments according to the Student Workseet (LKS) on the Edmodo 
assignment feature, making observations when collecting data according to the LKS, discussing assignments/questions in the LKS, answering teacher questions, express opinions, ask questions and irrelevant behavior. The process is a combination in the direct class and in the Edmodo class. According to (Nu'man, 2014) student activity in inquiry with Edmodo is the presence of challenges and the availability of initial material features.

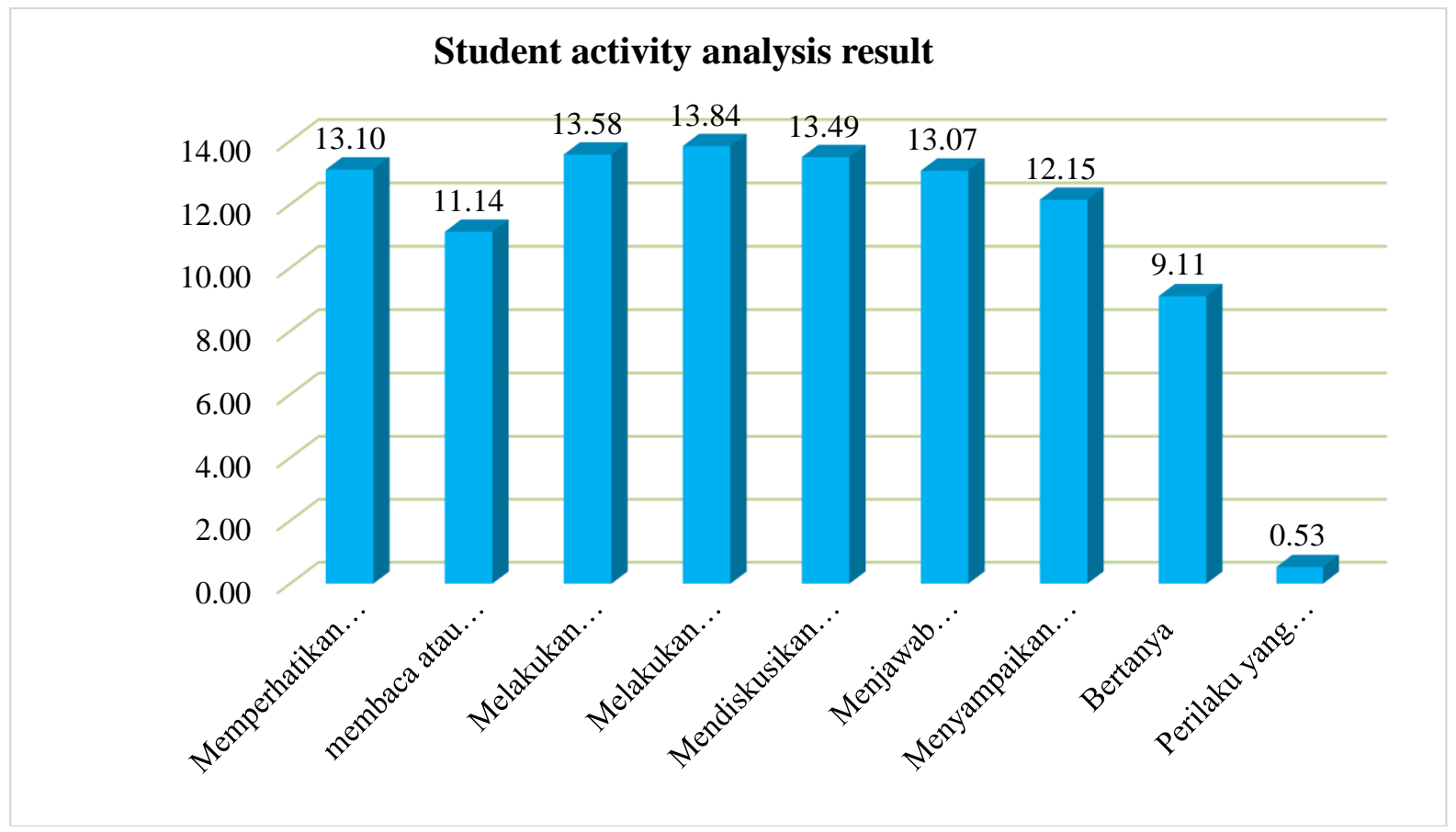

Figure 3. Students Activity Troughtout Learning

Based on Figure 3, information is obtained that the most dominant student activity is observing when data collection is in accordance with the LKS with an average value of $13.84 \%$. This is according to the scenario, where students investigate concepts that will be studied independently through activities working on worksheets that train critical thinking skills so as to minimize misconceptions. According to (Saputra, 2020) difficulties in reducing students' misconceptions and misunderstandings can be caused by students' old schemas that are difficult to change (in assimilation or accommodation) in a short time. Students must build their own knowledge or concepts that are in their minds through active involvement in every learning process that allows them to find facts and concepts for themselves, so that these facts and concepts become meaningful to them (Slavin, 1997).

Student activities during the learning process describe the activity. This is because the implementation of learning is very good, in accordance with the stages of guided inquirybased lesson plans with Edmodo, so that it can increase student activity. The above statement is supported by Handhika (2009), that the learning process through guided inquiry using experimental methods increases student activity which greatly affects concept understanding. According to (Ekayati, 2017) activeness in the application of Edmodo is carried out independently in the learning process.

Student responses, can be seen in the following Table 1.

Table 1. Recapitulation of student responses to learning

\begin{tabular}{clll}
\hline Nu & \multicolumn{1}{c}{ Question Description } & \multicolumn{2}{c}{ Average Rating/ Opinion (\%) } \\
\hline I. $\quad \begin{array}{l}\text { Students' opinions on the components: materials, student } \\
\text { textbooks, worksheets, learning atmosphere, how teachers } \\
\text { teach in class and Edmodo }\end{array}$ & $\begin{array}{l}\text { Very Interested } \\
94\end{array}$ & 6 \\
& $\begin{array}{l}\text { Students' opinions feel new about the components: lesson } \\
\text { material/content, student textbooks, worksheets, learning } \\
\text { atmosphere and the way teachers teach in the classroom }\end{array}$ & Very New 96 & Not New 4 \\
II. & &
\end{tabular}




\begin{tabular}{|c|c|c|c|}
\hline $\mathrm{Nu}$ & Question Description & \multicolumn{2}{|c|}{ Average Rating/ Opinion (\%) } \\
\hline & and Edmodo & & \\
\hline III & $\begin{array}{l}\text { Can understand the components: language in books, book } \\
\text { content, worksheets, evaluation sheets, and how teachers } \\
\text { teach in class and Edmodo }\end{array}$ & $\begin{array}{l}\text { Very Easy } \\
88,67\end{array}$ & $\begin{array}{l}\text { Not Easy } \\
11,33\end{array}$ \\
\hline IV & $\begin{array}{l}\text { Students' opinions feel new about LKS Inkuri guided by } \\
\text { Edmodo }\end{array}$ & Very New 96,67 & Not New 3,33 \\
\hline $\mathrm{V}$ & $\begin{array}{l}\text { Student responses if the next subject and other lessons use } \\
\text { the guided inquiry model }\end{array}$ & Agree 96,67 & Disagree 3,33 \\
\hline VI & $\begin{array}{l}\text { Student responses about teacher explanations and teacher } \\
\text { guidance during KBM in class and Edmodo }\end{array}$ & Clear 93,33 & Not Clear 3,33 \\
\hline VII & $\begin{array}{l}\text { Students' opinions about the questions of understanding } \\
\text { concepts and critical thinking skills }\end{array}$ & Easy 86,67 & $\begin{array}{l}\text { Not Easy } \\
13,33\end{array}$ \\
\hline
\end{tabular}

The overall results of filling out the response questionnaires given to students showed that students gave a positive response to guided inquiry-based learning with Edmodo. This positive response shows that students are enthusiastic during the learning process which makes students actively involved in a fun and meaningful learning experience, because basically in carrying out learning the most influential factor is the learning environment at school and in the Edmodo class. Learning must be interesting and fun according to student psychology (Akhfar \& Saputra, 2020). This is supported by the results of research by Apriliyana et al (2012), that inquiry-based learning has a positive influence on students' academic success and can develop students' critical thinking skills. Similarly, the results of research by Wulandari et al (2013), that the implementation of inquiry-based practicum can attract students' interest and motivation in learning, so that students give a positive response to the implementation of the learning that has been done.

Concept Understanding Learning Outcomes Test, can be seen in the following Figure 4.

\section{Concept Understanding Analysis Result}

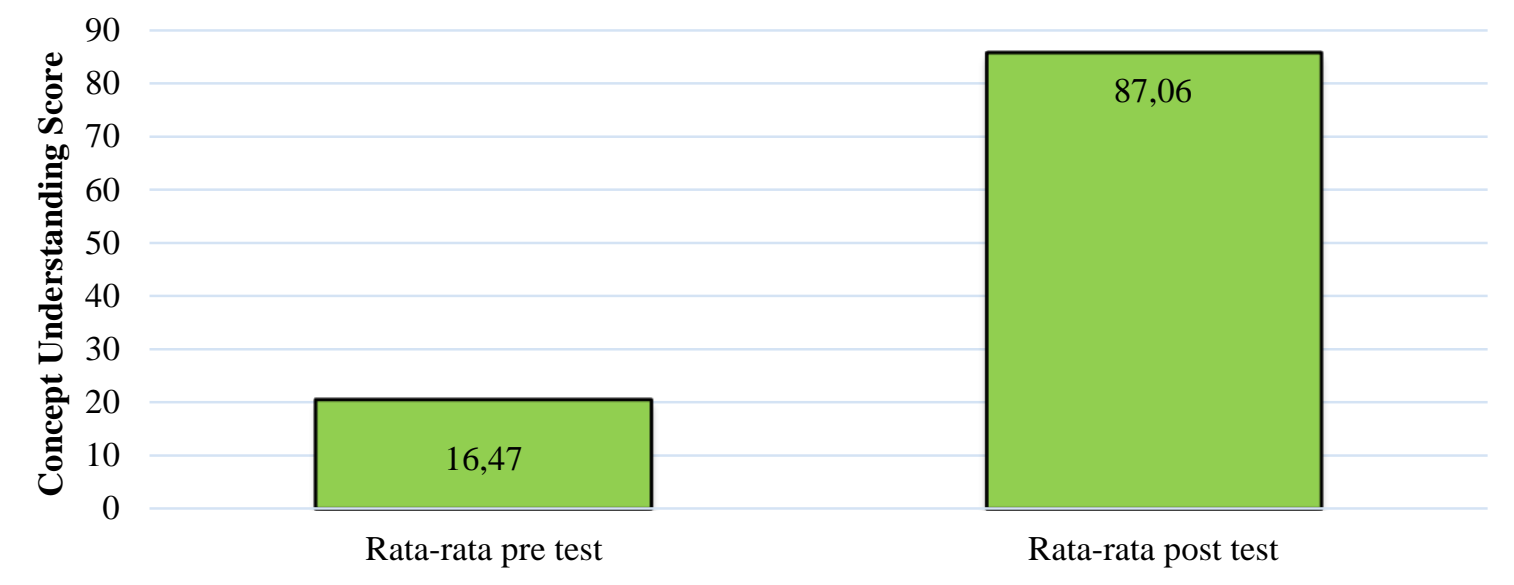

Figure 4. Concept Understanding Test Analysis Result

Based on Figure 4, information is obtained that in the pretest results all students have not reached the specified learning mastery 0.69 , after learning with the inquiry model with Edmodo, the posttest results show that all learning objectives can be achieved completely by $100 \%$ of students. Mastery of student learning reflects the improvement of students' concept understanding test. The increased understanding of students' concepts is certainly related to student activities during the learning process, especially interesting observation/experiment activities both in direct class and in Edmodo class. In these activities, students discover new knowledge for themselves with the guidance of the teacher. This is in accordance with the opinion of Bilgin (2009), guided inquiry learning can improve the understanding of students' concepts so that they can improve their learning outcomes. Bukhori (2012), based on research 
results that inquiry learning can improve students' understanding of concepts. Umrotun (2012), based on the results of the study, it was concluded that the use of learning models with guided inquiry techniques could improve the understanding of junior high school students' concepts. Similarly, the results of research conducted by Bransford, Brown \& Cocking (2000) in VMSC (2010), which showed that students who were involved in inquiry learning increased their learning outcomes about understanding, critical thinking, and problem solving skills in science. The increase in student learning outcomes is of course also a positive influence from the implementation of the Learning Implementation Plan, BAS, and LKS used in the learning process.

To find out how much influence the developed learning has on student learning outcomes, $\mathrm{N}$-gain score analysis is used. The effect of learning is said to be high if the gain value is greater than 0.7 (Hake, 1999). The results of the study obtained an average N-gain score of 0.84 in the high category. This can be interpreted that learning has a positive influence on students' understanding of concepts. The sensitivity analysis of 27 items of concept understanding in this study ranged from 0.43 to 0.97 . This shows that the questions presented have good sensitivity and are sensitive to guided inquiry learning.

The critical thinking test developed is in the form of an essay. As stated by Kardi (2002), that with essay questions, students are given sufficient freedom in synthesizing and evaluating, and the control is limited to efforts so that the questions in question can reveal the desired intellectual skills, and are used if students are required to provide explanations or reasons. state the kinds of relationships, describe the data, and formulate conclusions. This is in line with the Ministry of Education and Culture (2014) that written tests in the form of descriptions or essays require students to be able to remember, understand, organize, apply, analyze, synthesize, evaluate, and so on the material that has been studied, so as to be able to describe the domains of attitudes, knowledge, and skills. student skills.

Indicators of critical thinking skills in this study consist of; 1) identify problems, 2) formulate problems, 3) develop hypotheses, 4) determine manipulation variables, response variables and control variables, 5) formulate operational definitions of variables, 6) design experiments, 7) give arguments. The learning outcomes of critical thinking skills are measured using a critical thinking skills assessment sheet that has been validated by the validator.

Table 2. Completeness Critical Thinking Indicator Analysis Recapitulations

\begin{tabular}{clcccc}
\hline Quest & \multicolumn{1}{c}{ Indicator } & \multicolumn{2}{c}{ Answer Proportion } & \multicolumn{2}{c}{ Completeness Indicator } \\
\cline { 3 - 6 } Nu. & & U1 & U2 & U1 & U2 \\
\hline 28 & Problem indentification & 0,36 & 0,98 & $\mathrm{X}$ & $\mathrm{V}$ \\
29 & Formulate problem & 0,13 & 0,94 & $\mathrm{X}$ & $\mathrm{V}$ \\
30 & Formulate hypoteses & 0,98 & $\mathrm{X}$ & $\mathrm{V}$ \\
31 & Determine the manipulation variables, & 0,00 & 0,83 & $\mathrm{X}$ & $\mathrm{V}$ \\
32 & response variables and control variables & & & \\
33 & Determine operational definition variable & 0,00 & 0,72 & $\mathrm{X}$ & $\mathrm{V}$ \\
34 & Design experiment & 0,28 & 0,77 & $\mathrm{X}$ & $\mathrm{V}$ \\
35 & Design argumentation & 0,4 & 0,96 & $\mathrm{X}$ & $\mathrm{V}$ \\
36 & Design argumentation & 0,4 & 0,87 & $\mathrm{X}$ & $\mathrm{V}$ \\
37 & Design argumentation & 0,3 & 0,78 & $\mathrm{X}$ & $\mathrm{V}$ \\
\hline
\end{tabular}

Based on Table 2, information is obtained that before the inquiry model learning was applied, all critical thinking indicators did not reach the completeness value. After learning the inquiry model with Edmodo, all indicators are complete. 


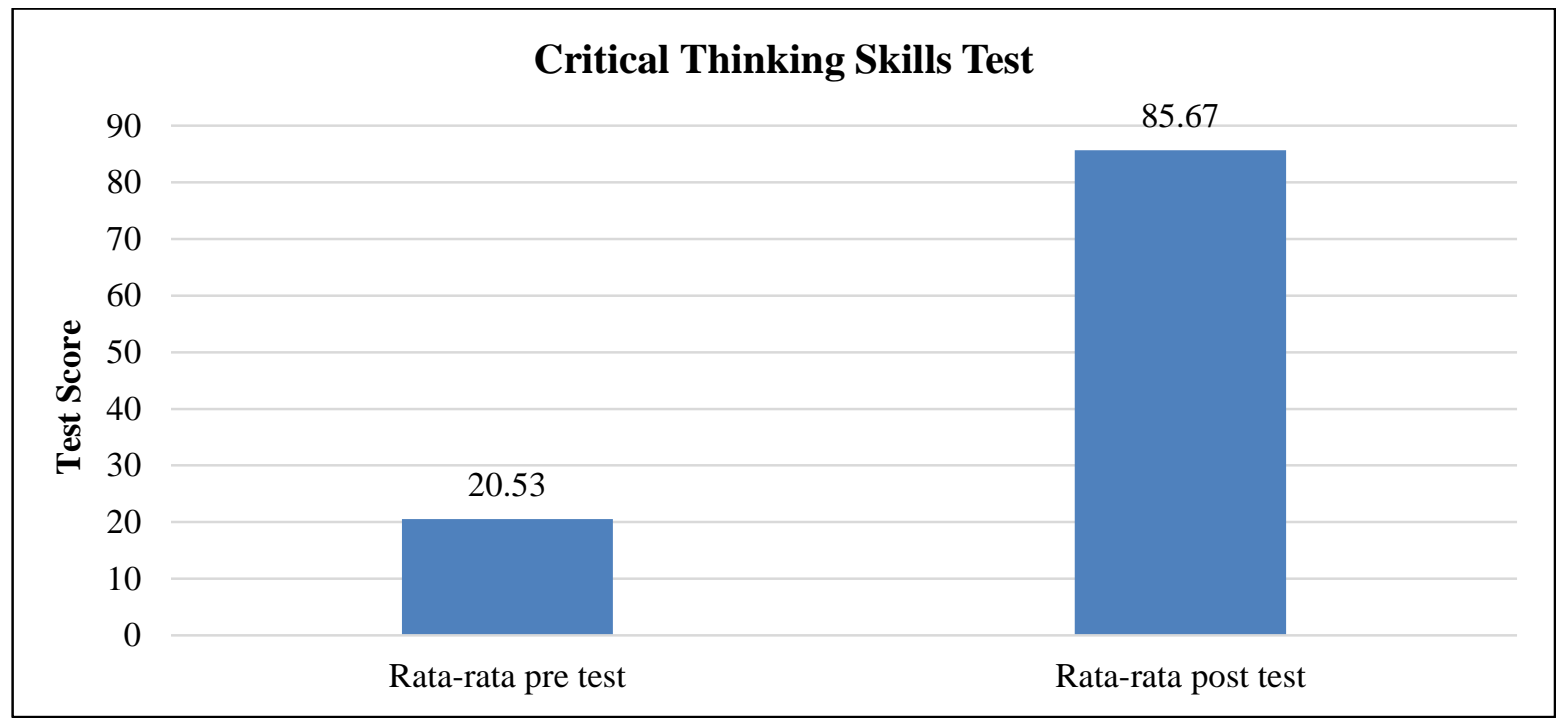

Figure 5. Critical Thinking Skills Test Abalysis Result

Based on Figure 5, information is obtained that the average critical thinking skills of students are very low (20.53). This is because students have never been taught critical thinking skills. So far, critical thinking skills are seen as not an important part of science learning. After participating in the teaching and learning activities of the guided inquiry model that trains critical thinking skills, students' critical thinking skills increase, with an average posttest of 85.67 with completeness indicators reaching $100 \%$. The average N-Gain score obtained by students is 0.82 which is in the high category. This means that learning has a high influence with the range of gain values above 0.7 Hake (1999). The results of this trial indicate that the guided inquiry model with Edmodo can practice critical thinking skills.

Table 3. Critical Thinking Question Butor Sensitivity

\begin{tabular}{llllll}
\hline \multirow{2}{*}{$\begin{array}{l}\text { Quest } \\
\mathrm{Nu}\end{array}$} & \multirow{2}{*}{ Indikator Soal } & \multicolumn{2}{l}{ Sum of Score } & \multirow{2}{*}{ Desctiption } \\
\cline { 3 - 5 } & & Post test & Pre test & & \\
\hline 28 & Problem indentification & 118 & 43 & 0,63 & sensitive \\
29 & Formulate problem & 170 & 23 & 0,82 & sensitive \\
30 & Formulate hypoteses & 176 & 24 & 0,84 & sensitive \\
31 & Determine the manipulation variables, response & 150 & 0 & 0,83 & sensitive \\
32 & variables and control variables & 130 & 0 & 0,72 & sensitive \\
33 & Determine operational definition variable & 138 & 51 & 0,48 & sensitive \\
34 & Design experiment & 115 & 48 & 0,56 & sensitive \\
35 & Design argumentation & 104 & 52 & 0,43 & sensitive \\
36 & Design argumentation & 94 & 36 & 0,48 & sensitive \\
37 & Design argumentation & 90 & 30 & 0,49 & sensitive \\
\hline
\end{tabular}

Table 3 shows the sensitivity of the item which states the sensitivity of the item to the influence of KBM. Items are declared sensitive to the learning process if they have a sensitivity of 0.3 (Arikunto, 2010). The higher the sensitivity value possessed by the item, the more sensitive the item is to the learning process that has been carried out. Based on table 4.21 , it can be seen that, all of the critical thinking skills test items have a sensitivity ranging from 0.48 to 0.87 . This shows that the questions to measure critical thinking skills developed by researchers have a good sensitivity value (Arikunto, 2010).

The description of critical thinking learning outcomes in this study is in accordance with the opinion of Bransford, Brown \& Cocking (2000) in VMSC (2010), which shows that inquiry learning with Edmodo can improve student learning outcomes regarding understanding, critical thinking, and problem solving skills in science. Similarly, Suryani (2009) found that guided discovery learning has a positive impact on the development of 
students' critical thinking skills related to the development of students' intelligence and has an influence on increasing students' learning motivation. In line with that Piaget (in Nur, 2000), knowledge comes from action, cognitive knowledge is largely determined by the extent to which students can manipulate and actively interact with the environment. Piaget's principles in teaching emphasize learning through discovery and real experience and the teacher's role in providing an environment that allows students to gain a wider variety of learning experiences. This study also supports the results of research investigated by Fuad (2013), showing that inquiry-based animation learning that has been developed is feasible to use to train students' critical thinking skills.

In general, the obstacle faced in each meeting is the learning process that has not been completed in accordance with the allotted time. This is because students are not used to doing inquiry-based worksheets with Edmodo which requires students' ability to perform critical thinking skills. In previous KBM, critical thinking skills have never been trained so that thinking skills are new for students, therefore it takes longer time to do inquiry-based worksheets. The time constraint experienced during the learning process, suggested a solution by reorganizing the time that has been set and must be adapted to student activities. All of the obstacles experienced during the learning process can still be overcome and do not make the inquiry-based learning presented experience significant obstacles.

Based on the results of the research data analysis and discussion, the following findings were obtained. First, the results of the RPP assessment get an average score of 3.55 in the good category, meaning that the RPP is feasible to use. Second, the results of the LKS assessment developed are suitable for students and teachers to use in training critical thinking skills and the LKS assessment instrument used is good with an average score of 3.44. Third, the results of the Student Textbook assessment get an average score of 3.38 with a good category, meaning that the Student Textbook developed is worthy of being used as a student and teacher guidebook in learning and the student book assessment instrument used is reliable. Fourth, the results of the validation of the Assessment Sheet for writing the concept understanding test items got a good category, and the critical thinking skills test got a good category. These results indicate that the Assessment Sheet is feasible to be used as a measuring tool for the achievement of basic competencies and the Assessment Sheet Instrument used is valid.

Fifth, the implementation of the RPP in the second trial was $100 \%$ with $97 \%$ reliability. This shows that the RPP can be implemented well and the RPP Implementation Instrument used can be said to be reliable. In addition, the results of observations of preliminary, core, closing activities, and class atmosphere on average got good grades. Sixth, the most dominant student activity is observing when collecting data in accordance with the LKS with a percentage of $13.84 \%$, conducting experiments according to the LKS guidelines with a percentage of $13.58 \%$, and paying attention to the teacher's explanation with a percentage of $13.10 \%$. This activity shows that the original teacher centered learning became student centered learning. The instrument for observing student activities used was reliable. Seventh, positive student responses to the learning process using the guided inquiry model with Edmodo, and training critical thinking skills. Eighth, the mastery of classical concept understanding test learning outcomes is $100 \%$, the sensitivity of the items ranges from 0.43 0.97 . Ninth, the completeness of critical thinking skills learning outcomes is $100 \%$, and the sensitivity of the items ranges from 0.48 to 0.84 . Tenth, the obstacles encountered in teaching and learning are related to the allocation of time and students' ability to build knowledge from the results of the experiment.

\section{CONCLUSION}

Based on the findings of the research, it can be concluded that the guided inquiry learning tool using Edmodo that was developed is suitable to be used to train the critical thinking skills of junior high school students. 


\section{RECOMMENDATION}

The use of this guided inquiry model is applied and studied in a limited class only, therefore it is recommended for teachers and subsequent researchers to research on a wider scope.

\section{ACKNOWLEDGMENT}

Authors thank to Head Master of SMP Negeri 17 Kendari and the teachers that participation in this research and also the students in participation as observed in this research.

\section{REFERENCES}

Adriani, D., Kemala, P., Lubis, D., Andi, M., \& Triono, A. (2019). Pengembangan modul mata kuliah metodologi penelitian pendidikan berbasis high order thinking skill (HOTS). Jurnal Pendidikan Ekonomi, 12(1), 27-36. https://doi.org/10.17977/UM014v12i12019p027

Akhfar, M., \& Saputra, I. G. P. E. (2020). Efektivitas strategi elaborasi PQ4R terhadap hasil belajar fisika siswa kelas VII SMP negeri 7 Sinjai. JPFT (Jurnal Pendidikan Fisika Tadulako Online), 8(2).

Apriliyana, Fitrihidayati, \& Raharjo. (2012). "Pengembangan perangkat pembelajaran berbasis inkuiri pada materi pencemaran lingkungan dalam upaya melatih keterampilan berpikir kritis siswa kelas X SMA”. BioEdu. Vol.1 No.3, pp. 39-43

Arends, R. (2007). Learning to teach. Yogyakarta: Pustaka Pelajar.

Arikunto, S. (2010). Dasar-dasar evaluasi pendidikan. Jakarta: Bina Aksara.

Balram, R. (2017). Pengaruh metode praktikum disertai feedback terhadap hasil belajar dan respon siswa kelas X pada materi larutan. Jurnal Pendidikan Dan Pembelajaran Khatulistiwa, 6(6), 1-12. https://jurnal.untan.ac.id/index.php/jpdpb/article/view/20305

Basori, B. (2013). Pemanfaatan social learning network "Edmodo" dalam membantu perkuliahan teori bodi otomotif di prodi PTM JPTK FKIP UNS. Jurnal Ilmiah Pendidikan Teknik Dan Kejuruan, 6(2), 99-105. https://doi.org/10.20961/jiptek.v6i2.12562

Bilgin, I. (2009). "The effects of guided inquiry instruction incorporating a cooperative learning approach on university students' achievement of acid and bases concepts and attitude toward guided inquiry instruction”. Scientific Research and Essay. Vol.4 (10), pp. 1038-1046.

Bukhori, A.F. 2012. "Pembelajaran berbasis inkuiri untuk optimalisasi pemahaman konsep fisika pada siswa di SMA negeri 4 Magelang, Jawa Tengah”. Journal Berkala Fisika Indonesia. Vol. 4 No. 2. pp. 11-21.

BSNP. (2006). Panduan penyusunan KTSP. Jakarta: Depdiknas.

Dick, W., \& Carrey, L. (2009). The systematic design of instruction. Florida: Harper Collins Publishers.

Djidu, H., \& Jailani. (2016). Fostering student's higher-order thinking skill through problembased learning in calculus. Proceeding of 3rd International Conference on Research, Implementation and Education of Mathematics and Science, 127-130.

Djidu, H., \& Jailani, J. (2017). Model pembelajaran kalkulus SMA berbasis masalah untuk meningkatkan kemampuan berpikir tingkat tinggi siswa. Parama Publishing.

Djidu, H., \& Retnawati, H. (2018). Cultural values-integrated mathematical learning model to develop HOTS and character values. In E. Retnowati, A. Ghufron, Marzuki, Kasiyan, A. C. Pierawan, \& Ashadi (Eds.), Character Education for 21st Century Global Citizens (pp. 363-370). Routledge. https://doi.org/10.1201/9781315104188-46

Ekayati, R. (2017). Optimalisasi aplikasi edmodo dalam meningkatkan kemandirian belajar dan kesadaran berbahasa mahasiswa pada mata kuliah literary criticism di FKIP UMSU. EduTech: Jurnal Ilmu Pendidikan Dan Ilmu Sosial, 3(1), 148-165. 
https://doi.org/10.30596/EDUTECH.V3I1.992

Emda, A. (2017). Laboratorium sebagai sarana pembelajaran kimia dalam meningkatkan pengetahuan dan ketrampilan kerja ilmiah. Lantanida Journal, 2(2), 218. https://doi.org/10.22373/lj.v2i2.1409

Ennis, R.H. (1985). Goals for a critical thinking curriculum. In A. Costa (Ed). Developing Mind: A Resource Book for Teaching Thinking. Alexandria V A: Association for Supervision and Curriculum Development.

Ennis, R.H. (1996). Critical thinking. USA: Prentice-Hall, Inc.

Fuad, N.M. (2013). Pengembangan media pembelajaran animasi berbasis inkuiri pada sistem eksresi manusia untuk melatihkan keterampilan berpikir kritis siswa (Tesis magister pendidikan tidak dipublikasikan). Universitas Negeri Surabaya.

Gay, E., \& Sofyan, N. (2017). The effectiveness of using edmodo in enhancing studentsâ outcomes in advance writing course of the fifth semester at FIP - UMMU. Journal of English Education, 2(1), 1-11. https://doi.org/10.31327/jee.v2i1.217

Hake, R.R. (1999). American educational research association's division d, measurement and research methodology: analyzing change/gain scores. USA: Woodland Hills.

Halil, N. I. (2020). The effectiveness of using edmodo as an online learning platform in Covid-19. Jurnal Penelitian Dan Pengkajian Ilmu Pendidikan: E-Saintika, 4(3), 284298. https://doi.org/10.36312/E-SAINTIKA.V4I3.316

Handhika, J. (2009). Pembelajaran fisika melalui inkuiri terbimbing dengan metode eksperimen dan demonstrasi ditinjau dari aktivitas dan perhatian mahasiswa. $J P 2 F$. Vol 1 No.1 Tahun 2009. pp 9-20.

Hassoubah, Z.I. (2004). Developing creative and critical thinking skills, cara berpikir kreatif dan kritis. Bandung: Nuansa.

Hidayati, D. N. (2015). Pengaruh model pembelajaran inkuiri terbimbing (guided inquiry) terhadap kemampuan berpikir kritis siswa SMA pada mata pelajaran geografi [Universitas Negeri Malang]. http://mulok.library.um.ac.id/index3.php/70305.html

HL, N. I., Saputra, I. G. P. E., Sejati, A. E., \& Syarifuddin, S. (2020). Developing teaching material bajo's local wisdom sea preservation Thomson-Brooks/Cole model. JPI (Jurnal Pendidikan Indonesia), 9(3), 355. https://doi.org/10.23887/jpi-undiksha.v9i3.23234

Hunaidah, M., Sukariasih, L., \& Saputra, I. G. P. E. (2019). Penerapan model pembelajaran discovery untuk meningkatkan keterampilan proses sains dan penguasaan konsep ipa peserta didik kelas VIIID SMP Kartika XX-6 Kendari. JPFT (Jurnal Pendidikan Fisika Tadulako Online), 7(3).

Jahring, Nasruddin, \& Farida I (2020) The effectiveness of mind mapping learning models based on contextual learning on mathematical problem solving abiliy. Proceeding of USN Kolaka-ADRI International Conference on Sustainable, 1, pp. 64-68. Doi: 10.31327/icusn-adri.v1i0.1177

Jailani, J., Sugiman, S., Retnawati, H., Bukhori, Apino, E., Djidu, H., \& Arifin, Z. (2018). Desain pembelajaran matematika: untuk melatihkan higher order thinking skills $(\mathrm{H}$. Retnawati (ed.)). UNY Press.

Jailani, Jailani, Heri Retnawati, H. R., Wulandari, N. F., \& Djidu, H. (2020). Mathematical literacy proficiency development based on content, context, and process. Problems of Education in the 21st Century, 78(1), 80-101. https://doi.org/10.33225/pec/20.78.80

Kardi, S. (2002). Mengembangkan tes hasil belajar. Surabaya. Departemen Pendidikan Nasional Universitas Negeri Surabaya.

Kemdikbud (2014). Materi pelatihan guru implementasi kurikulum 2013 tahun ajaran 2014/2015, mata pelajaran IPA SMP/MTs. Jakarta: Kementerian Pendidikan dan Kebudayaan.

Kurniawan, R., \& Djidu, H. (2021). Kemampuan literasi matematis siswa: Sebuah studi literatur. EDUMATIC: Jurnal Pendidikan Matematika, 2(1), 24-30.

Meador (2010). Introduction to inquiry physics a modified learning cycle curriculum. 
Bartlesville high school. http://inquiryphysics.org.

Miller, M. D., Linn, R. L., \& Gronlund, N. E. (2009). Measurement and assessment in teaching. In Library of Congress Catalogging in Publication Data. Pearson Education, Inc.

Nasruddin, N., Mashuri, S., \& Nafiah, U. (2020). Peningkatan hasil belajar matematika pada materi segitiga melalui pendekatan penemuan terbimbing siswa SMP. Jurnal Penelitian Dan Pengkajian Ilmu Pendidikan: E-Saintika, 4(2), 80. https://doi.org/10.36312/esaintika.v4i2.169

Nasruddin, N., \& Abidin, Z. (2017). Meningkatkan hasil belajar matematika melalui model pembelajaran kooperatif tipe Jigsaw pada siswa SMP. Journal of Educational Science $\begin{array}{lllll}\text { and Technology (EST). UNM Makassar. 3(2), 113-121. } & \text {. }\end{array}$ https://doi.org/10.26858/est.v3i2.3557.

National Research Council. (2011). Inkuiri dan standar-standar pendidikan sains nasional sebuah panduan untuk pengajaran dan pembelajaran. Washington DC: National Academy Press.

Ningrum, D. J., Mahardika, I. K., \& Gani, A. A. (2015). Pengaruh model quantum teaching dengan metode praktikum terhadap kemampuan multipresentasi siswa pada mata pelajaran fisika kelas X di SMA Plus Darul Hikmah. Jurnal Pendidikan Fisika, 4(2), 116-120. https://jurnal.unej.ac.id/index.php/JPF/article/view/1873/1540

Nu'man, A. Z. (2014). Efektifitas penerapan e-learning model edmodo dalam pembelajaran pendidikan agama islam terhadap hasil belajar siswa (Studi Kasus: SMK Muhammadiyah 1 Sukoharjo). In DutaCom Journal (Vol. 7, Issue 1).

Nur, M. (2011). Model pembelajaran berdasarkan masalah. Surabaya: Unesa PSMS.

Nur, M. dan Wikandari, P.R. (2000). Pengajaran berpusat kepada siswa dan pendekatan konstruktivistik dalam pengajaran. Surabaya: Unesa.

Nurul H., D., Amaluddin, L. O., \& Surdin, S. (2017). The effect guided inquiry to critical thinking ability to build student character in geography subject. 1st International Conference on Geography and Education (ICGE 2016), 367-371. https://doi.org/10.2991/icge-16.2017.71

Pavelich, M.J., \& Abraham, M.R. (1979). An inquiry format laboratory program for general chemistry. Journal of chemichal education.Vol 56. pp $100-103$.

Rahmawati (2012). Pengembangan perangkat pembelajaran dengan metode pembelajaran penemuan terbimbing (Guided Discovery Learning) untuk melatih keterampilan berpikir kritis pada siswa SMP. (Tesis Magister pendidikan tidak dipublikasikan). Universitas Negeri Surabaya.

Retnawati, H., Hadi, S., Munadi, S., Hadiana, D., Muhardis, M., Apino, E., Djidu, H., Rafi, I., Yusron, E., \& Rosyada, M. N. (2019). When national examination no longer determining graduation, will students accomplish it seriously? Indonesian Journal of Educational Assesment, 2(2), 40-49. https://doi.org/10.26499/ijea.v2i2.34

Saputra, I. G. P. E. (2020). Penguasaan konsep fisika siswa menggunakan pendekatan konflik kognitif pada materi gerak lurus di SMK Negeri 2 Watubangga. JPFT (Jurnal Pendidikan Fisika Tadulako Online), 8(3).

Saputra, I. G. P. E., \& Sukariasih, L. (2019). Penerapan pembelajaran creative problem solving untuk meningkatkan keterampilan berpikir kritis fisika peserta didik kelas XIIPA 3 SMA Negeri 1 Watubangga. JPFT (Jurnal Pendidikan Fisika Tadulako Online), 7(3), 16-21.

Saputra, I. G. P. E., Harnipa, H., \& Akhfar, M. (2021). Development of science learning device oriented guided inquiry with virtual laboratory to train science process skills of junior high school students in Kendari. Jurnal Penelitian \& Pengembangan Pendidikan Fisika, 7(1), 13-22. https://doi.org/10.21009/1.07102

Sembiring, Y. A., \& Zagoto, D. (2017). Pengaruh model pembelajaran kooperatif tipe think pair share (tps) dengan bantuan praktikum terhadap hasil belajar fisika. In Jurnal 
EduMatSains (Vol. 1, Issue 2). https://doi.org/10.33541/EDUMATSAINS.V1I2.242

Slavin, R.E,. (1997). Educatianal psycology: Theory and Practise. Massachusetts: Allyn and Bacon.

Sukariasih, L., Sahara, L., Reskiawan, B., \& Nursalam, L. O. (2019). Improving the Skill of Physics Science Process through Guide Discovery Method in Students at Senior High School.

Sukariasih, L., Saputra, I. G. P. E., Ikhsan, F. A., Sejati, A. E., \& Nisa, K. (2019). Improving the learning outcomes of knowledge and inquiry skill domain on third grade students of smp negeri 14 kendari through the guided inquiry learning model assisted by science KIT. Geosfera Indonesia, 4(2), 175. https://doi.org/10.19184/geosi.v4i2.10097

Suparmi, M. (2013). Pengembangan perangkat pembelajaran biologi berorientasi inkuiri untuk meningkatkan kemampuan berpikir kritis dan kemampuan kerjasama siswa SMA. (Tesis magister pendidikan tidak dipublikasikan). Universitas Negeri Surabaya.

Suryani, N.D. (2009). Pengembangan keterampilan berpikir kritis siswa pada pembelajaran fisika untuk materi pokok kalor melalui model pembelajaran penemuan (guided descovery) di kelas X-3 SMA Negeri 1 Gedangan. Jurnal Pendidikan Delta Widya. Jilid 2 No 2 Tahun 2009.

Umrotun. (2012). Peningkatan kemampuan pemahaman konsep optik melalui tehnik inkuiri terbimbing pada peserta didik kelas VIII semester genap tahun ajaran 2011/2012. Jurnal Penelitian Pembelajaran Fisika. Vol. 3 No. 1 2012. pp.74-82.

Vajoczki, S., Watt, S., Vine, M.M., \& Liao. (2011). Inquiry of learning: Level, dicipline, class size, what matter?. International journal for the scholarship of teaching and learning. Vol 5 No.1. pp 1-11.

VMSC, V.M. (2010). Scientific Inquiry and the nature of science task force report. Virginia, USA: VMSC.

Wasis dan Irianto (2008). Ilmu Pengetahuan Alam SMP dan MTs Kelas VIII. Jakarta: Depdiknas.

Wityafrianti. (2013). Peningkatan kemampuan berwudhu dengan menggunakan metode praktik murid kelas II di sekolah dasar negeri 15 Air Jamban Duri Kabupaten Bengkalis [Universitas Islam Negeri Sultan Syarif Kasim Riau]. http://repository.uinsuska.ac.id/5577/1/2013_2013557PAI.pdf

Wulandari, A.D., Kurnia, \& Sunarya, Y. (2013). Pembelajaran praktikum berbasis inkuiri terbimbing untuk meningkatkan keterampilan berpikir kritis siswa SMA pada materi laju reaksi. Jurnal riset dan praktik pendidikan kimia. Universitas Pendidikan

Yana, A. U., Antasari, L., \& Kurniawan, B. R. (2019). Analisis pemahaman konsep gelombang mekanik melalui aplikasi online quizizz. Jurnal Pendidikan Sains Indonesia (Indonesian Journal of Science Education), 7(2), 143-152. https://doi.org/10.24815/jpsi.v7i2.14284

Yustika, A., Supardi, \& Ali, M. (2017). Pengaruh model pembelajaran kooperatif tipe think pair share (TPS) berbasis praktikum terhadap hasil belajar siswa di SMP Negeri 2 Palembang. In Seminar Nasional Pendidikan IPA (Vol. 1, Issue 1). http://conference.unsri.ac.id/index.php/semnasipa/article/view/727 